\title{
Development of Eggplant Diseases with Reference to Meteorological Parameter in Kymore Zone of Madhya Pradesh, India
}

\author{
Krishan Kant Dhakad*, M.S. Bhale and S.N. Singh \\ Department of Plant Pathology, JNKVV Jabalpur-482004, Madhya Pradesh, India \\ *Corresponding author
}

\begin{tabular}{|l|}
\hline Key w or d s \\
Eggplant diseases, \\
Disease \\
distribution, \\
Disease \\
development
\end{tabular}

A B S T R A C T

Eggplant (Solanum melongena L.) is an important Solanaceous crop widely grown in different parts of the country. Incidence of Phomopsis fruit rot was observed at $39^{\text {th }}$ standard week (October 2016) till $3^{\text {rd }}$ standard week (January 2017) and incidence ranged from 2.0-22.0\%. Almost 10 time increase in fruit rot was recorded within 30 days during October 2016 when the average temperature $23.65^{\circ} \mathrm{C}$ with $55.5 \%$ relative humidity having 9.3 sunshine hours. The incidence ranged from $4.0-13.0 \%$ during $56^{\text {th }}$ standard week (maximum temperature $30.7^{\circ} \mathrm{C}$ and minimum $13.6^{\circ} \mathrm{C}$ with relative humidity (morning $82 \%$ and evening $92 \%$ ) provided the congenial condition and incidence up to $13.0 \%$ was recorded. Bacterial wilt was not recorded at early stage however, the plant were infected during pre-fruiting incidence of bacterial wilt which ranged from 4.0-13.0\% under natural field condition. The leaf spot (Cercospora melongenae) increased up to five times (3.0$15.0 \%)$ from $43^{\text {rd }}-46^{\text {th }}$ week when the average temperature was $18.2^{\circ} \mathrm{C}$ with morning humidity $88 \%$. and remained constant till $49^{\text {th }}$ week. Pin prick method was better and typical symptoms on eggplant fruits were developed within 3-6 days in Pusa Round and 69 days in Pusa Purple long inoculated by Phomopsis vexans. In case of test virulence of Cercospora melongenae it took 4-6 days of development and 7-8 days in pusa round and Pusa Purple Long, respectively

\section{Introduction}

Brinjal or eggplant (Solanum melongena L.) is an important Solanaceous crop of sub tropics and tropics. The bringal, eggplant or Aubergine (French name) has originated in Indian sub-continent and China (Thompson and Kelly, 1957). India is considered to be the Centre of Origin of cultivated eggplant, from where it spread to the other parts of the world (Choudhury and Malda, 1968). Eggplant contains $92.7 \mathrm{~g}$ moisture, $1.4 \mathrm{~g}$ of proteins and $4.0 \mathrm{~g}$ of carbohydrates, $0.3 \mathrm{~g}$ minerals, 124
I.U. vitamins and $12.0 \mathrm{mg}$ vitamin C per $100 \mathrm{~g}$ of edible portion (Kalra et al., 1988). It is low in calories and fat, contain mostly water, little protein, fibre and carbohydrate, water soluble sugars, and vitamins (Bajaj et al., 1979).

Unripe fruits are used primarily as vegetable throughout the country. It is also used as raw material in pickle making (Singh et al., 1963). It is used as an excellent remedy for those suffering from liver complaints. Eggplant fruit is used in ayurvedic medicine for curing the diabetes. 
The eggplant crop is affected by several plant pathogens at different growth stages. Important diseases are damping off (Pythium spp), Phomopsis blight (Phomopsis vexans), leaf spot (Cercospora melongenae), leaf spot (Alternaria melongenae), little leaf (Phytoplasma) and collor rot (Sclerotium rolfsii) (Bhupendra et al., 2014). Symptoms of leaf blight, fruit rot, leaf spot, stem canker and damping off of eggplant caused by Phomopsis vexans has been studied (Edgerton and Moreland, 1921 and Vishunavat, 1992). At different growth stages the crop suffers from various diseases during all the growing season (Ahmed and Hossain, 1985).

\section{Materials and Methods}

The experiments were conducted at Seed Technology Research Experimental Area, Department of Plant Breeding \& Genetics, JNKVV, Jabalpur. The investigations were conducted on the crop grown during 2016-17 at Jabalpur. The location site lies between $22^{\circ} 49^{\prime}$ and $22^{\circ} 80^{\prime}$ North latitude and $78^{\circ} 2^{\prime}$ and $80^{\circ} 58^{\prime}$ East longitude at an altitude of 411.78 meter above the mean sea level.

\section{Development of diseases under field condition}

The progressive development of Phomopsis blight, bacterial wilt, Alternaria leaf spot, Cercospora leaf spot was determined on crop grown under natural field. The development of disease was correlated with weather parameters such as temperature, relative humidity, rainfall during growth period with standard weeks. The plants were pre- tagged and observations on the progressive development were determined.

\section{Meteorological data}

During 2016-2017, the data on rainfall, relative humidity, minimum-maximum temperature were obtained from the Meteorological Observatory, College of Agricultural Engineering, JNKVV, Jabalpur (MP) (Table 1).

\section{Test of virulence}

The virulence of Phomopsis vexans and Cercospora melongenae was tested by pin prick and tooth pick prick method under natural field condition small bits of Phomopsis vexans culture was inserted in the fruit wall small bit of infected portion was inoculated in the leaves.

\section{Symptomatology}

The symptoms caused by different pathogens were critically observed and documented. Symptoms incited at nursery stage, prefruiting stage and fruiting stage were recorded. The association of pathogen was identified on the basis of cultural characteristics and symptoms caused.

\section{Identification of diseases}

\section{Collection of infected eggplant parts}

During present study, infected leaves, fruits and stem were collected in paper envelopes and brought to the laboratory. The samples so collected were numbered and stored in paper envelops at $4^{\circ} \mathrm{C}$ to avoid any further deterioration.

\section{Isolation, purification and identification of fungi}

Fruits, twigs, leaves and seeds from infected plants/fruits were collected from different locations. Isolations were made to determine the associated mycoflora. The diseased plant parts were cut into small pieces. Surface sterilized with $0.1 \% \mathrm{NaOCI}$ for 30 seconds and there after placed in Petri dishes 
containing $17-20 \mathrm{ml}$ of solidified PSA mixed with small quantity of streptopenicillin to avoid bacterial contamination. The Petri dishes were incubated at $25 \pm 2{ }^{\circ} \mathrm{C}$. After 4 to 7 days incubation, the developing fungi were sub cultured on PSA medium and purified.

\section{Results and Discussion}

Development of eggplant diseases was recorded at seven days interval on pre-tagged randomly selected plants. Periodically observations were recorded on the particular plant during this investigation.

\section{Development of phomopsis fruit blight}

Development of diseases was recorded at research experimental field variety Pusa round. The incidence of phomopsis fruit blight/fruit rot was observed on $39^{\text {th }}$ standard week (I week of October, 2016) till $3^{\text {rd }}$ standard week (January, 2017) during $39^{\text {th }}$ standard week of phomopsis fruit blight incidence was $2.0 \%$ and during this period average temperature was $26.7^{\circ} \mathrm{C}$ (Maximum $29.9^{\circ} \mathrm{C}$ and Minimum $23.5^{\circ} \mathrm{C}$ ) with $94.0 \%$ relative humidity in the morning and $83.0 \%$ relative humidity in the evening. Prior to $39^{\text {th }}$ week $91.8 \mathrm{~mm}$ rains were received in six days. The incidence of fruit blight increased from $2.0 \%\left(39^{\text {th }}\right.$ week) to $19.0 \%\left(42^{\text {nd }}\right.$ week) and $22.0 \%$ ( $43^{\text {rd }}$ standard week) almost 10 times increase in the incidence of fruit blight was recorded within 30 days during October, 2016. During $43^{\text {rd }}$ week the incidence was $22.0 \%$ that was coincided with average temperature $23.65^{\circ} \mathrm{C}$ (maximum $31.7^{\circ} \mathrm{C}$ and minimum $\left.16.6^{\circ} \mathrm{C}\right)$ with $55.5 \%$ relative humidity (morning $82.0 \%$ and evening $29.0 \%$ ) having 9.3 sunshine hours per day during November, 2016 between $44^{\text {th }}-47^{\text {th }}$ standard week only $3.0 \%$ increase in disease incidence was noticed and it reached $35.0 \%$ in $58^{\text {th }}$ standard week. The development of fruit blight remained stagnant during II fortnight of
December to II fortnight of January (35\%) during this period maximum temperature was $24.42^{\circ} \mathrm{C}$ and minimum $6.82^{\circ} \mathrm{C}$, the humidity during this period ranged from $84-91 \%$ in the morning and $28-48 \%$ in the evening with range of sunshine hours 6.5-8.6 hours the incidence of phomopsis fruit blight was in the range of $2.0-35.0 \%$ during October to December, 2016 (Table 2).

\section{Development of bacterial wilt}

The prevalence of bacterial wilt under natural field condition, bacterial wilt was not recorded at early stage however, the plant were infected during pre-fruiting incidence of bacterial wilt which ranged from 4.0-13.0\% under natural field condition. Initiation of bacterial wilt was noticed when the average temperature was $26.7^{\circ} \mathrm{C}$ and average relative humidity was $46.0 \%$ with $52.4 \mathrm{~mm}$ rainfall during $39^{\text {th }}$ standard week (I week of October, 2016) with the incidence of $4.0 \%$ a graduate development till $43^{\text {th }}$ week was noticed $(4.0-7.0 \%$ incidence). It reached up to $13.0 \%$ during $46^{\text {th }}$ week during $43^{\text {rd }}$ week maximum temperature $30.7^{\circ} \mathrm{C}$ and minimum $15.6^{\circ} \mathrm{C}$. having morning relative humidity $82 \%$ and evening $92 \%$ the sunshine hours are maximum (9.3 hours) that might have provided the continued condition from $46^{\text {th }}$ standard week onward the incidence remained constant up to $49^{\text {th }}$ standard week (Table 3).

\section{Development of Cercospora leaf spot}

Development of Cercospora leaf spot was recorded on pre tagged plant variety Pusa round by adopting fixed plot monitoring system. Data presented in Table 4 indicate that Cercospora leaf spot was initiated during $42^{\text {nd }}$ week when the maximum temperature was $31.5^{\circ} \mathrm{C}$ and minimum $15.4^{\circ} \mathrm{C}$ (average $23.45^{\circ} \mathrm{C}$ ) with morning humidity $91 \%$ (Average humidity 61.5\%). It was observed that incidence of Cercospora leaf spot 
increased up to five times (3.0-15.0\%) from $43^{\text {rd }}-46^{\text {th }}$ week, at this stage average temperature was $18.2^{\circ} \mathrm{C}$ with morning humidity $88 \%$. Cercospora leaf spot incidence ranged from 3.0-15.0\% and remained constant till $49^{\text {th }}$ week.

\section{Test of virulence}

Test of virulence of Phomopsis vexans and Cercospora melongenae was verified by two methods.

\section{Phomopsis vexans}

Virulence of Phomopsis vexans was evaluated by pin prick and tooth pick prick method. On fruit from naturally infected fruits small portion of affected part was picked up with the help of biological niddle and inserted into healthy fruit and small infected part was picked with the help of tooth pick and inserted in the fruits separately. Data presented in Table 5 indicate that in pin prick method infection and typical symptoms developed within 3-6 days in Pusa round, 6-9 days in Pusa purple long and 3-5 days in local variety of eggplant. Tooth pick prick method took 612 days for development of the disease after inoculation on an eggplant fruit under natural condition.

\section{Cercospora melongenae}

Disease development by pin prick and tooth pick prick methods were adopted. Small bit was transferred from diseased leaves to healthy leaves for evaluation of disease development.

Table.1 Weekly meteorological data (2016-2017)

\begin{tabular}{|c|c|c|c|c|c|c|c|c|c|}
\hline \multirow[t]{2}{*}{ Months } & \multirow{2}{*}{$\begin{array}{c}\text { Standard } \\
\text { Weeks }\end{array}$} & \multicolumn{2}{|c|}{ Temperature $\left({ }^{\circ} \mathrm{C}\right)$} & \multicolumn{2}{|c|}{ Relative humidity $(\%)$} & \multirow[t]{2}{*}{ Rainfall (mm) } & \multirow[t]{2}{*}{ Wind velocity } & \multirow{2}{*}{$\begin{array}{l}\text { Rainy } \\
\text { days }\end{array}$} & \multirow{2}{*}{$\begin{array}{c}\text { Sunshine } \\
\text { Hr/day }\end{array}$} \\
\hline & & Max. & Min. & Mor. & Eve. & & & & \\
\hline \multirow{4}{*}{$\begin{array}{c}\text { September } \\
2016\end{array}$} & 36 & 30.6 & 23.0 & 87 & 63 & 06.9 & 04.5 & 017.6 & 02 \\
\hline & 37 & 31.7 & 23.6 & 89 & 65 & 04.5 & 01.9 & 018.0 & 01 \\
\hline & 38 & 33.0 & 23.9 & 92 & 64 & 03.5 & 06.7 & 03.80 & 00 \\
\hline & 39 & 29.9 & 23.5 & 94 & 83 & 04.0 & 04.6 & 052.4 & 03 \\
\hline \multirow[t]{5}{*}{ October } & 40 & 31.9 & 23.9 & 93 & 64 & 03.0 & 07.3 & 024.2 & 02 \\
\hline & 41 & 31.5 & 21.3 & 88 & 51 & 04.2 & 08.0 & 0000 & 00 \\
\hline & 42 & 31.5 & 15.4 & 91 & 32 & 02.5 & 09.3 & 0000 & 00 \\
\hline & 43 & 31.7 & 15.6 & 82 & 29 & 02.9 & 08.8 & 0000 & 00 \\
\hline & 44 & 29.7 & 12.3 & 87 & 34 & 02.4 & 08.7 & 0000 & 00 \\
\hline \multirow[t]{4}{*}{ November } & 45 & 29.7 & 10.6 & 91 & 24 & 02.2 & 08.1 & 0000 & 00 \\
\hline & 46 & 28.3 & 08.1 & 88 & 24 & 02.0 & 08.1 & 0000 & 00 \\
\hline & 47 & 28.8 & 08.4 & 87 & 23 & 01.4 & 08.3 & 0000 & 00 \\
\hline & 48 & 28.8 & 08.7 & 89 & 27 & 01.7 & 08.7 & 0000 & 00 \\
\hline \multirow[t]{4}{*}{ December } & 49 & 25.1 & 07.9 & 93 & 43 & 02.1 & 06.2 & 0000 & 00 \\
\hline & 50 & 26.1 & 07.3 & 91 & 28 & 02.0 & 07.8 & 0000 & 00 \\
\hline & 51 & 24.7 & 05.5 & 91 & 30 & 01.8 & 07.4 & 0000 & 00 \\
\hline & 52 & 25.7 & 05.6 & 88 & 29 & 01.9 & 08.6 & 0000 & 00 \\
\hline \multirow[t]{5}{*}{ January 2017} & 1 & 23.9 & 09.1 & 20 & 48 & 02.8 & 06.5 & 0000 & 00 \\
\hline & 2 & 21.7 & 06.6 & 86 & 42 & 02.9 & 07.2 & 000.2 & 00 \\
\hline & 3 & 24.1 & 09.2 & 89 & 47 & 03.1 & 06.4 & 0000 & 00 \\
\hline & 4 & 25.7 & 10.1 & 97 & 45 & 02.9 & 06.5 & 003.2 & 01 \\
\hline & 5 & 25.4 & 07.5 & 92 & 38 & 02.3 & 09.6 & 0000 & 00 \\
\hline \multirow[t]{4}{*}{ February } & 6 & 27.2 & 09.8 & 84 & 42 & 03.2 & 09.0 & 0000 & 00 \\
\hline & 7 & 26.4 & 10.6 & 95 & 42 & 02.9 & 08.4 & 13.20 & 01 \\
\hline & 8 & 29.7 & 10.0 & 83 & 26 & 03.3 & 10.3 & 0000 & 00 \\
\hline & 9 & 31.2 & 11.1 & 80 & 26 & 02.6 & 10.2 & 0000 & 00 \\
\hline \multirow[t]{4}{*}{ March } & 10 & 30.3 & 12.5 & 72 & 24 & 04.5 & 09.6 & 0000 & 00 \\
\hline & 11 & 29.3 & 09.8 & 74 & 16 & 02.7 & 10.1 & 0000 & 00 \\
\hline & 12 & 33.9 & 14.4 & 75 & 19 & 03.4 & 10.0 & 002.8 & 01 \\
\hline & 13 & 38.6 & 15.9 & 69 & 15 & 03.5 & 10.3 & 0000 & 00 \\
\hline \multirow[t]{2}{*}{ April } & 14 & 39.3 & 20.6 & 41 & 15 & 06.1 & 10.0 & 0000 & 00 \\
\hline & 15 & 38.1 & 14.4 & 54 & 09 & 03.7 & 10.2 & 0000 & 00 \\
\hline
\end{tabular}


Table.2 Progressive development of Phomopsis fruit blight during 2016-17 (Variety Pusa round)

\begin{tabular}{|c|c|c|c|c|c|c|c|c|c|}
\hline \multirow[t]{2}{*}{ Month } & \multirow[t]{2}{*}{$\begin{array}{c}\text { Standard } \\
\text { week }\end{array}$} & \multirow{2}{*}{$\begin{array}{c}\text { Percent } \\
\text { Phompsis fruit } \\
\text { blight }\end{array}$} & \multicolumn{2}{|c|}{ Temperature $\left({ }^{\circ} \mathrm{C}\right)$} & \multicolumn{2}{|c|}{$\begin{array}{l}\text { Relative Humidity } \\
(\%)\end{array}$} & \multirow[t]{2}{*}{$\begin{array}{l}\text { Rainfall } \\
\text { (mm) }\end{array}$} & \multirow[t]{2}{*}{$\begin{array}{l}\text { Rainy } \\
\text { Days }\end{array}$} & \multirow[t]{2}{*}{$\begin{array}{l}\text { Sunshine } \\
\text { Hour /day }\end{array}$} \\
\hline & & & Maximum & Minimum & I & II & & & \\
\hline \multirow[t]{3}{*}{ September 16} & 36 & 0.0 & 30.6 & 23.0 & 87 & 63 & 17.6 & 02 & 04.5 \\
\hline & 37 & 0.0 & 31.7 & 23.6 & 89 & 65 & 18.0 & 01 & 01.9 \\
\hline & 38 & 0.0 & 33.0 & 23.9 & 92 & 64 & 03.8 & 00 & 06.7 \\
\hline \multirow[t]{5}{*}{ October 16} & 39 & 2.0 & 29.9 & 23.5 & 94 & 83 & 52.4 & 03 & 04.6 \\
\hline & 40 & 2.0 & 31.9 & 23.9 & 93 & 64 & 24.2 & 02 & 07.3 \\
\hline & 41 & 5.0 & 31.5 & 21.3 & 88 & 51 & 00 & 00 & 08.0 \\
\hline & 42 & 19.0 & 31.5 & 15.4 & 91 & 32 & 00 & 00 & 09.3 \\
\hline & 43 & 22.0 & 31.7 & 15.6 & 82 & 29 & 00 & 00 & 09.3 \\
\hline \multirow[t]{4}{*}{ November 16} & 44 & 27.0 & 29.7 & 12.3 & 87 & 34 & 00 & 00 & 08.8 \\
\hline & 45 & 27.0 & 29.7 & 10.6 & 91 & 24 & 00 & 00 & 08.1 \\
\hline & 46 & 30.0 & 28.3 & 08.1 & 88 & 24 & 00 & 00 & 08.1 \\
\hline & 47 & 30.0 & 28.8 & 08.4 & 87 & 23 & 00 & 00 & 08.3 \\
\hline \multirow[t]{5}{*}{ December 16} & 48 & 32.0 & 28.8 & 08.7 & 89 & 27 & 00 & 00 & 08.7 \\
\hline & 49 & 32.0 & 25.1 & 07.9 & 93 & 43 & 00 & 00 & 06.2 \\
\hline & 50 & 35.0 & 26.1 & 07.3 & 91 & 28 & 00 & 00 & 07.8 \\
\hline & 51 & 35.0 & 24.7 & 05.5 & 91 & 28 & 00 & 00 & 07.4 \\
\hline & 52 & 35.0 & 25.7 & 05.6 & 88 & 29 & 00 & 00 & 08.6 \\
\hline \multirow[t]{4}{*}{ January 17} & 01 & 35.0 & 23.9 & 09.1 & 84 & 48 & 00 & 00 & 06.5 \\
\hline & 02 & 35.0 & 21.7 & 06.6 & 86 & 42 & 0.2 & 00 & 07.2 \\
\hline & 03 & 30.0 & 24.1 & 09.2 & 89 & 47 & 00 & 00 & 06.4 \\
\hline & 04 & - & 25.7 & 10.1 & 97 & 45 & 3.2 & 01 & 06.5 \\
\hline
\end{tabular}

(-) Not recorded due to consistent prevalence 
Table.3 Progressive development of bacterial wilt during 2016-17 (Variety Pusa round)

\begin{tabular}{|c|c|c|c|c|c|c|c|c|c|}
\hline \multirow[t]{2}{*}{ Month } & \multirow{2}{*}{$\begin{array}{l}\text { Standard } \\
\text { week }\end{array}$} & \multirow{2}{*}{$\begin{array}{c}\text { Bacterial } \\
\text { wilt }\end{array}$} & \multicolumn{2}{|c|}{ Temperature (C) } & \multicolumn{2}{|c|}{ Relative Humidity (\%) } & \multirow{2}{*}{$\begin{array}{c}\text { Rainfall } \\
\text { (mm) }\end{array}$} & \multirow{2}{*}{$\begin{array}{l}\text { Rainy } \\
\text { Days }\end{array}$} & \multirow{2}{*}{$\begin{array}{l}\text { Sunshine } \\
\text { Hour /day }\end{array}$} \\
\hline & & & Maximum & Minimum & I & II & & & \\
\hline \multirow[t]{3}{*}{ September 16} & 36 & 0.0 & 30.6 & 23.0 & 87 & 63 & 17.6 & 02 & 04.5 \\
\hline & 37 & 0.0 & 31.7 & 23.6 & 89 & 65 & 18.0 & 01 & 01.9 \\
\hline & 38 & 0.0 & 33.0 & 23.9 & 92 & 64 & 03.8 & 00 & 06.7 \\
\hline \multirow[t]{5}{*}{ October 16} & 39 & 4.0 & 29.9 & 23.5 & 94 & 83 & 52.4 & 03 & 04.6 \\
\hline & 40 & 7.0 & 31.9 & 23.9 & 93 & 64 & 24.2 & 02 & 07.3 \\
\hline & 41 & 7.0 & 31.5 & 21.3 & 88 & 51 & 00 & 00 & 08.0 \\
\hline & 42 & 7.0 & 31.5 & 15.4 & 91 & 32 & 00 & 00 & 09.3 \\
\hline & 43 & 7.0 & 31.7 & 15.6 & 82 & 29 & 00 & 00 & 09.3 \\
\hline \multirow[t]{4}{*}{ November 16} & 44 & 11.0 & 29.7 & 12.3 & 87 & 34 & 00 & 00 & 08.8 \\
\hline & 45 & 11.0 & 29.7 & 10.6 & 91 & 24 & 00 & 00 & 08.1 \\
\hline & 46 & 13.0 & 28.3 & 08.1 & 88 & 24 & 00 & 00 & 08.1 \\
\hline & 47 & 13.0 & 28.8 & 08.4 & 87 & 23 & 00 & 00 & 08.3 \\
\hline \multirow[t]{2}{*}{ December 16} & 48 & 13.0 & 28.8 & 08.7 & 89 & 27 & 00 & 00 & 08.7 \\
\hline & 49 & 13.0 & 25.1 & 07.9 & 93 & 43 & 00 & 00 & 06.2 \\
\hline
\end{tabular}

Table.4 Progressive development of Cercospora leaf spot during 2016-17 (Variety Pusa Round)

\begin{tabular}{|c|c|c|c|c|c|c|c|c|c|}
\hline \multirow[t]{2}{*}{ Month } & \multirow{2}{*}{$\begin{array}{l}\text { Standard } \\
\text { week }\end{array}$} & \multirow{2}{*}{$\begin{array}{c}\text { Cercospora leaf } \\
\text { spot }\end{array}$} & \multicolumn{2}{|c|}{ Temperature (C) } & \multicolumn{2}{|c|}{ Relative Humidity (\%) } & \multirow{2}{*}{$\begin{array}{l}\text { Rainfall } \\
\text { (mm) }\end{array}$} & \multirow{2}{*}{$\begin{array}{l}\text { Rainy } \\
\text { Days }\end{array}$} & \multirow{2}{*}{$\begin{array}{l}\text { Sunshine } \\
\text { Hour /day }\end{array}$} \\
\hline & & & Maximum & Minimum & $\mathbf{I}$ & II & & & \\
\hline \multirow[t]{3}{*}{ September 16} & 36 & 0.0 & 30.6 & 23.0 & 87 & 63 & 17.6 & 02 & 04.5 \\
\hline & 37 & 0.0 & 31.7 & 23.6 & 89 & 65 & 18.0 & 01 & 01.9 \\
\hline & 38 & 0.0 & 33.0 & 23.9 & 92 & 64 & 03.8 & 00 & 06.7 \\
\hline \multirow[t]{5}{*}{ October 16} & 39 & 0.0 & 29.9 & 23.5 & 94 & 83 & 52.4 & 03 & 04.6 \\
\hline & 40 & 0.0 & 31.9 & 23.9 & 93 & 64 & 24.2 & 02 & 07.3 \\
\hline & 41 & 0.0 & 31.5 & 21.3 & 88 & 51 & 00 & 00 & 08.0 \\
\hline & 42 & 3.0 & 31.5 & 15.4 & 91 & 32 & 00 & 00 & 09.3 \\
\hline & 43 & 3.0 & 31.7 & 15.6 & 82 & 29 & 00 & 00 & 09.3 \\
\hline \multirow[t]{4}{*}{ November 16} & 44 & 11.0 & 29.7 & 12.3 & 87 & 34 & 00 & 00 & 08.8 \\
\hline & 45 & 12.0 & 29.7 & 10.6 & 91 & 24 & 00 & 00 & 08.1 \\
\hline & 46 & 15.0 & 28.3 & 08.1 & 88 & 24 & 00 & 00 & 08.1 \\
\hline & 47 & 15.0 & 28.8 & 08.4 & 87 & 23 & 00 & 00 & 08.3 \\
\hline \multirow[t]{2}{*}{ December 16} & 48 & 15.0 & 28.8 & 08.7 & 89 & 27 & 00 & 00 & 08.7 \\
\hline & 49 & 15.0 & 25.1 & 07.9 & 93 & 43 & 00 & 00 & 06.2 \\
\hline
\end{tabular}


Table.5 Development of disease after inoculation on leaves and fruits of eggplant

\begin{tabular}{|c|c|c|c|c|c|}
\hline \multirow{2}{*}{ Pathogen } & Method & Plant & \multicolumn{3}{|c|}{ Symptoms appeared days / variety } \\
\hline Phomopsis & Part & Pusa Purple Long & Pusa Round & Local \\
\hline vexans & Pooth pick prick & Fruit & $7-9$ & $3-6$ & $3-5$ \\
\hline $\begin{array}{c}\text { Cercospora } \\
\text { melongenae }\end{array}$ & Fruit & $9-12$ & $6-8$ & $6-8$ \\
\hline
\end{tabular}

Test conducted during II week of November, 2016

In Pusa round it took 4-6 days for development of infection in tooth prick method. It took about 6-11 days for development of disease in Pusa purple long by tooth prick method and about 11 days required for infection and in Pusa round it required 7-11 days whereas in local variety within 9 days development was noticed.

Phomopsis fruit rot was first noticed at $39^{\text {th }}$ standard week (I week of October 2016) till $3^{\text {rd }}$ standard week (January 2017) and incidence ranged from 2.0-22.0\%. Almost 10 time increase in fruit rot was recorded within 30 days during October 2016 when the average temperature $23.65^{\circ} \mathrm{C}$ with $55.5 \%$ relative humidity having 9.3 sunshine hours. During $58^{\text {th }}$ standard week the incidence reached up to $35.0 \%$ (October, 2016) Influences of temperature and relative humidity on the development of fruit rot symptoms caused by Phomopsis vexans has been studies by Chowdhary and Hasija (1979) and Ahmed (1987). Fruit rot development under laboratory condition has been studied by Islam and Sitansu (1990), and Singh and Chouhan (1984).

Under natural field condition bacterial wilt was not recorded at early plant stage however, the plant infection was noticed at pre-fruiting stage. The incidence ranged from $4.0-13.0 \%$ during $56^{\text {th }}$ standard week (maximum temperature $30.7^{\circ} \mathrm{C}$ and minimum $13.6^{\circ} \mathrm{C}$ with relative humidity (morning 82\% and evening 92\%) provided the congenial condition and incidence up to $13.0 \%$ was recorded. Goto (1990) and Kelman (1953) studied the development of bacterial wilt in eggplant.
The leaf spot (Cercospora melongenae) increased up to five times (3.0-15.0\%) from $43^{\text {rd }}-46^{\text {th }}$ week when the average temperature was $18.2^{\circ} \mathrm{C}$ with morning humidity $88 \%$. Cercospora leaf spot incidence ranged from $3.0 \%$ to $15.0 \%$ and remained constant till $49^{\text {th }}$ week. Ullasa and Sohi (1987) reported that development of leaf spot due to Cercospora melongenae was favored by high humidity, warm days and cool night. These factors have been identified for the ideal infection role of weather on the development of leaf spot disease. The virulence of Phomopsis vexans and Cercospora melongenae was verified by pin prick and tooth pick prick method under natural field condition. A small bit of Phomopsis vexans infected tissue was inserted in the fruit wall while small bit of infected portion was inoculated in the leaves, respectively. Pin prick method was comparatively better and typical symptoms on eggplant fruits developed within 3-6 days in Pusa Round and 6-9 days in Pusa Purple Long inoculated by Phomopsis vexans.In case of test virulence of Cercospora melongenae it took 4-6 days for development and 7-8 days in pusa round and pusa purple long respectively.

Incidence of Phomopsis fruit rot was observed at $39^{\text {th }}$ standard week (I week of October 2016) till $3^{\text {rd }}$ standard week (January 2017) and incidence ranged from 2.0-22.0\%. Almost 10 time increase in fruit rot was recorded within 30 days during October 2016 when the average temperature $23.65^{\circ} \mathrm{C}$ with $55.5 \%$ relative humidity having 9.3 sunshine hours. The incidence ranged from $4.0-13.0 \%$ during $56^{\text {th }}$ standard week (maximum temperature $30.7^{\circ} \mathrm{C}$ 
and minimum $13.6^{\circ} \mathrm{C}$ with relative humidity (morning 82\% and evening 92\%) provided the congenial condition and incidence up to $13.0 \%$ was recorded. Bacterial wilt was not recorded at early stage. The leaf spot (Cercospora melongenae) increased up to five times (3.0$15.0 \%)$ from $43^{\text {rd }}-46^{\text {th }}$ week when the average temperature was $18.2^{\circ} \mathrm{C}$ with morning humidity $88 \%$. Cercospora leaf spot incidence ranged from $3.0-15.0 \%$ and remained constant till $49^{\text {th }}$ week.

Pin prick method was better and typical symptoms on eggplant fruits were developed within 3-6 days in Pusa Round and 6-9 days in Pusa Purple long inoculated by Phomopsis vexans. In case of test virulence of Cercospora melongenae it took 4-6 days development and 7-8 days in pusa round and pusa purple long, respectively.

\section{References}

Ahmed HU and Hossain MM. 1985. Crop disease survey and establishment of a herbarium at BARI, Plant Pathology Division, BARI, Joydebpur, Gazipur. p: 107.

Bajaj KL, Kaur G and Chadha ML. 1979. Glycoalkaloid content and other chemical constituents of the fruits of some eggplant (Solanum melonena L.) varieties. Journal Plant Food. 3:163-168.

Bhupendra KS, Singh S, and Yadav SM, 2014. Some important plant pathogenic diseases of brinjal (Solanum melongena L.) and their management. Plant Pathology. 13(13): 208-213

Choudhury B and Malada TS. 1968. Brinjal: A vegetable of masses. Indian Horticulture.
12: 21-22.

Chowdhury SR and Hasija SK. 1979. Pathological studies on Phomopsis vexans causing soft rot of brinjal fruits. Indian Phytopathology. 32(3): 495-496.

Edgerton CW and Moreland CC. 1921. Eggplant blight Louisiana Agricultural Experiment Station Bulletin. 178, pp 144.

Goto M. 1990. Fundamentals of Bacterial Plant Pathology. Academic Press, Inc. 1250 Sixth Avenue, San Diego, CA, USA.

Kalra CL, Berry SK and Sehgal RC. 1988. A resume on brinjal (Solanum melongena L.), a most common vegetable. Indian Fedration Packer, 2; 46-59.

Kelman A. 1953. The bacterial wilt caused by Pseudomonas solanacearum. North Carolina Agricultural Experiment Station Technical Bulletin. 99: 194 pp.

Singh RS and Chouhan JS. 1984. Some fruits of water melon in northern India. Indian Journal Mycology and Plant Pathology. 14: 279-280.

Singh S, Krishnakumar S and Katyal SL. 1963. Fruit culture in India. Indian Council of Agriculture Research, New Delhi. pp: 412.

Thompson CH and Kelly CW.1957. Vegetable Crops. Mc Graw Hill Book Co.Inc. New York. 501p.

Ullasa BA and Sohi HS. 1987. Studies on Cercospora leaf spot disease of brinjal in Karnataka. Vegetable Science. 14(1): 9297.

Vishunavat K. 1992. Phomopsis blight and fruit rot of eggplant. In Plant Diseases of International Importance Vol II. Diseases of Vegetables and Oil Seed Crops.

\section{How to cite this article:}

Krishan Kant Dhakad, M.S. Bhale and Singh, S.N. 2018. Development of Eggplant Diseases with Reference to Meteorological Parameter in Kymore Zone of Madhya Pradesh, India. Int.J.Curr.Microbiol.App.Sci. 7(08): 3811-3818. doi: https://doi.org/10.20546/ijcmas.2018.708.389 